\title{
Feeding resource partitioning between two understorey insectivorous birds in a fragment of Neotropical cloud forest
}

\author{
M. A. Manhães ${ }^{a}$, M. M. Dias ${ }^{b}$ and A. L. C. Lima \\ anstituto de Ciências Biológicas, Universidade Federal de Juiz de Fora - UFJF, Campus Universitário, \\ Rua José Lourenço Kelmer, s/n, São Pedro, CEP 36036-900, Juiz de Fora, MG, Brazil \\ ${ }^{b}$ Departamento de Ecologia e Biologia Evolutiva, Universidade Federal de São Carlos - UFSCar, \\ Rodovia Washington Luiz, Km 235, SP-310, CEP 13565-905, São Carlos, SP, Brazil \\ 'Programa de Pós-graduação em Ecologia e Conservação de Recursos Naturais, Instituto de Biologia, Universidade \\ Federal de Uberlândia - UFU, Campus Umuarama, Rua João Naves de Ávila, 2121, \\ CEP 38400-902, Uberlândia, MG, Brazil \\ *e-mail: marcomanhaes1@yahoo.com.br
}

Received: May 12, 2014 - Accepted: July 22, 2014 - Distributed: November 30, 2015

(With 3 figures)

\begin{abstract}
The food habits and niche overlap based on diet composition and prey size of two species of understorey insectivorous birds were investigated in an area of montane rain forest in the state of Minas Gerais, southeastern Brazil. A total of 43 birds were captured: 33 individuals of Conopophaga lineata (Conopophagidae) with 13 recaptures, and 10 individuals of Myiothlypis leucoblephara (Parulidae) with 12 recaptures, from which were obtained respectively 33 and 10 fecal samples. Fragments of 16 groups of arthropods, plus insect eggs, were identified in these samples. Conopophaga lineata predominantly consumed Formicidae (32\%) and Isoptera (23.6\%). However, the index of alimentary importance (AI) of Isoptera (3.53) was lower than other groups such as Formicidae (AI =61.88), Coleoptera $(\mathrm{AI}=16.17)$, insect larvae $(\mathrm{AI}=6.95)$ and Araneae $(\mathrm{AI}=6.6)$. Myiothlypis leucoblephara predominantly consumed Formicidae $(28.2 \%)$ and Coleoptera (24.4\%), although Coleoptera and Hymenoptera non-Formicidae had the highest values of AI (38.71 and 22.98 respectively). Differences in the proportions of the types of arthropods consumed by birds were not enough to reveal their separation into feeding niches (overlap $=0.618, \mathrm{p}$ observed $\leq$ expected $=0.934$ ), whereas differences in the use of resources was mainly due to the size of the prey $(\mathrm{p}<0.001)$, where $C$ lineata, the species with the highest body mass $(\mathrm{p}<0.001)$ consumed larger prey. It is plausible that prey size is an axis of niche dimension that allows the coexistence of these species.
\end{abstract}

Keywords: birds, cloud forest, insectivores, Neotropical region, niche.

\section{Partição de recursos alimentares entre duas espécies de aves insetívoras de sub-bosque em um fragmento de floresta nebular Neotropical}

\section{Resumo}

Os hábitos alimentares e a sobreposição de nicho em termos de composição da dieta e tamanho de presas de duas espécies de aves insetívoras de sub-bosque foram investigados em uma área de floresta ombrófila altomontana no estado de Minas Gerais, sudeste do Brasil. Foram capturados 33 indivíduos de Conopophaga lineata (Conopophagidae), com 13 recapturas, e 10 indivíduos de Myiothlypis leucoblephara (Parulidae), com 12 recapturas, dos quais foram obtidas, respectivamente, 33 e 10 amostras fecais, onde foram identificados fragmentos de 16 grupos de artrópodes, além de ovos de insetos. Conopophaga lineata consumiu predominantemente Formicidae (32\%) e Isoptera (23,6\%). Contudo, o índice de importância alimentar (IA) de Isoptera $(3,53)$ esteve abaixo de outros grupos como Formicidae $(\mathrm{IA}=61,88)$, Coleoptera $(\mathrm{IA}=16,17)$, larva de inseto $(\mathrm{IA}=6,95)$ e Araneae $(\mathrm{IA}=6,6)$. Myiothlypis leucoblephara consumiu predominantemente Formicidae $(28,2 \%)$ e Coleoptera $(24,4 \%)$, embora em termos de IA o predomínio tenha sido de Coleoptera $(\mathrm{IA}=38,71)$ e Hymenoptera não Formicidae $(\mathrm{IA}=22,98)$. Diferenças nas proporções dos tipos de artrópodes consumidos pelas aves não foram suficientes para revelar separação em seus nichos alimentares $($ sobreposição $=0,618 ; \mathrm{p}$ observado $\leq$ esperado $=0,934)$, ao passo que divergências no uso de recursos se deram principalmente em função dos tamanhos das presas $(\mathrm{p}<0,001)$, onde C. lineata, a espécie com maior massa corporal, $(\mathrm{p}<0,001)$ consumiu as maiores presas. É plausível que o tamanho das presas seja um eixo da dimensão do nicho que permite a coexistência dessas espécies.

Palavras-chave: aves, floresta nebular, insetívoros, região Neotropical, nicho. 


\section{Introduction}

The coexistence of species in a place can be determined by the occupation of different ecological niches, and some of the main axes that drive niche occupation are habitat, temporal activity and diet (Pianka, 1973; Schoener, 1974). Recent measurements of the niche overlap of small and medium-sized vertebrates of the Neotropical region have revealed that the coexistence of species, with reduced interspecific interactions or interference competition, may occur mainly as a result of interactions between species using different types of resources at small spatial scale, regardless of their taxonomic relationships (e.g. Bergallo and Rocha, 1994; Martinez, 2004; Vieira and Port, 2006; Castro-Arellano and Lacher Junior, 2009).

Even with this recent data accumulation on resource partitioning among vertebrates in the Neotropics, however, the literature is still scant, especially considering the high species richness and diversity of habitats in this region. In this context, studies on forest birds are scarce (e.g. Rodrigues, 1995; Naoki, 2007; Hasui et al., 2009), presumably due to the complexity of forest environments and vegetation structure that, in turn, influences how birds forage, as well as habitat selection patterns and community structure (Robinson and Holmes, 1982).

Understorey insectivorous birds in tropical forests usually have high habitat specificity and difficulty moving through areas that lack forest cover (Willis, 1979; Stouffer and Bierregaard Junior, 1995). These characteristics may be useful in research on feeding ecology and competition, since flows of bird populations from this vegetation strata among forest fragments are, generally, not intense (Yabe et al., 2010; Marini, 2010). Furthermore, the composition of the diet of insectivorous birds may be related to factors such as competition or the reduced abundance of arthropods as a food resource (Blake and Hoppes, 1986; Naranjo and Ulloa, 1997), or difference in body size between syntopic species (Hespenheide, 1971).

Here we investigate the niche relationships between two species of insectivorous passerines of the lower forest strata, common in southeastern Brazil: Myiothlypis leucoblephara (Vieillot, 1817) (White-browed Warbler, Parulidae) and Conopophaga lineata (Wied, 1831) (Rufous Gnateater, Conopophagidae). These birds regularly forage on the forest floor (D'Angelo Neto et al., 1998; Pacheco et al., 2008) and are often sympatric and even syntopic in many areas of their occurrence (e.g. D'Angelo Neto et al., 1998; Krauczuk, 2008; Pacheco et al., 2008). The aim is to assess whether these two syntopic species of birds differ in the width of their feeding niches, types (in general, taxa), or prey size and, if so, whether the differences are related to body mass.

\section{Material and Methods}

\subsection{Study area}

The study was conducted in the Ibitipoca State Park, an area of 1488 ha, situated at $21^{\circ} 42$ ' $33^{\prime \prime} \mathrm{S}, 43^{\circ} 53$ ' $07^{\prime}$ ' W, in the state of Minas Gerais, southeastern Brazil. Phytophysiognomy is dominated by rocky outcrops, grasslands, rain forests and riparian forests. Sampling occurred in an area of tropical cloud forest (Carvalho et al., 2000) of approximately 90 ha, known as "Mata Grande". The regional climate is characterized by a mean annual temperature of $18.9^{\circ} \mathrm{C}$ (Aragona and Setz, 2001), and average annual rainfall of 1,544 $\mathrm{mm}$ (Carvalho et al., 2000), with dry winters and rainy summers (Manhães, 2003; Manhães et al., 2010).

\subsection{Sampling}

Samples were collected monthly from January to December 2004 in Mata Grande (MGR). The birds were captured with mist-nets $(12 \mathrm{~m} \times 38 \mathrm{~mm}$ mesh, $3 \mathrm{~m}$ high) installed at ground level and arranged in lines of nine nets in five pre-existing understorey trails, distant from 84 to $818 \mathrm{~m}$ one each other, with a total of 3178 mist-net hours. The captured birds were marked with numbered aluminum bands provided by CEMAVE/ICMBio and weighed with $50 \mathrm{~g}$ Pesola scales.

\subsection{Diet}

The birds were held in cloth bags for approximately 30 minutes to obtain fecal samples. After releasing the birds near the net-line, feces found in the bags were removed and transferred to paper envelopes or conserved in $70 \%$ alcohol. The feces, kept dry, were diluted in boiling water in test-tubes to clean the material and eliminate uric acid (Ralph et al., 1985). All samples were then filtered in filter paper and dried in a stove. Each sample was examined in a Petri dish under a stereoscopic microscope (10x to 40x). The fragments were identified based on guides provided by several authors (Ralph et al., 1985; Moreby, 1988; Chapman and Rosenberg, 1991; Whitaker Junior, 1998; Burger et al., 1999; Gomes et al., 2001; Manhães et al., 2010; Triplehorn and Johnson, 2011) and also by comparison with structures of arthropod specimens taken from the habitat.

The preys were classified to the lowest taxonomic level possible, generally order (family for Formicidae) according to Triplehorn and Johnson (2011) and McGavin (2000). Fragments of holometabolous insects were grouped into a single category, "insect larvae" (Burger et al., 1999). To determine the minimum number of preys in each sample we considered color, size, shape and number of unique structures, such as heads, and paired structures such as mandibles or wings. The size of the preys were obtained from the size of fragments found in the feces applied in linear regression equations for many taxonomic groups found in the diet, as calculated by Manhães and Dias (2008).

\subsection{Niche overlap}

To correct the importance of items that occur abundantly but sporadically in the samples, or items registered frequently but always in small amounts, we calculated an Index of Alimentary Importance (AI) for diet based only on arthropods, according to Durães and Marini (2005) (Equation 1).

$A I_{\mathrm{i}}=\left(R O_{\mathrm{i}} \times \overline{R A}_{\mathrm{i}} / \sum_{\mathrm{i}=1}^{n}\left(R O_{\mathrm{i}} \times \overline{R A}_{\mathrm{i}}\right)\right) \times 100$ 
where: $\mathrm{AI}=$ Index of Alimentary Importance; $R O_{\mathrm{i}}=$ number of samples where the category $i$ occurs relative to the total number of samples (n) per species; $R A_{\mathrm{i}}=$ number of items in the diet in category $i$ relative to the total number of items in a given sample, $\overline{R A}_{\mathrm{i}}=$ mean relative abundance of each diet category $i$.

Niche overlap was then calculated on the basis of AI of each type of prey $i$ using Pianka's index (Pianka, 1973), and analyzed by statistically comparing the observed value with expected values obtained by randomization, via the Monte Carlo method, using the software EcoSim 7.72 (Gotelli and Entsminger, 2004). In this case, we used randomization algorithm 3 (RA3), which retains the niche breadth of each species, but randomizes which particular resource states are utilized.

\subsection{Niche width and prey size}

Niche width was calculated using Levins' index (Levins, 1968) and a set of pseudo-values were obtained by the Jackknife method, according to Jaksic (2000). The pseudo-values of niche width, the sizes of prey consumed obtained by regression equations, and bird body masses were compared using the Monte Carlo method (1000 permutations) for the Mann-Whitney test, using the software PAST v. 3.01 (Hammer et al., 2001). The few food plant items found in the samples were considered accidental or occasional consumption, and were not included in the quantitative analysis. Insect eggs may have been ingested along with female arthropods laying eggs and also were not analyzed.

\section{Results}

We obtained 68 captures of 43 individuals, being 33 individuals of $C$. lineata (13 recaptures) and 10 of $M$. leucoblephara (12 recaptures). Table 1 shows the food items found in 33 fecal samples of $C$. lineata and 10 of $M$. leucoblephara, as well as their respective proportions and the alimentary importance of each food item in the diet of each species.

We identified fragments of 16 arthropod groups in the fecal samples of both species, excluding insect eggs. The most frequent item was Hymenoptera Formicidae. This was the most important item in the $\operatorname{diet}$ of $C$. lineata. Isoptera was the second most frequent in the total of items but consumed only by $C$. lineata, although with low relative importance in the diet. Another item with high frequency in the diet of both species was Coleoptera, and these prey were the most important in the diet of M. leucoblephara, followed by non-Formicidae Hymenoptera (Table 1). Together, these four groups of arthropods constituted $71.9 \%$ of the preys found in all fecal samples. Other important

Table 1. Diet composition of Myiothlypis leucoblephara and Conopophaga lineata in Ibitipoca State Park based on fecal samples.

\begin{tabular}{|c|c|c|c|c|c|c|c|c|c|}
\hline \multirow[b]{2}{*}{ Feeding items } & \multicolumn{4}{|c|}{ M. leucoblephara } & \multicolumn{4}{|c|}{ C. lineata } & \multirow[b]{2}{*}{ Total } \\
\hline & Freq. & $\%$ & AI & $\begin{array}{l}\text { Size range } \\
\text { in } \mathbf{m m}(\mathbf{n})\end{array}$ & Freq. & $\%$ & AI & $\begin{array}{l}\text { Size range } \\
\text { in } \mathrm{mm}(\mathrm{n})\end{array}$ & \\
\hline Orthoptera & & & & & 3 & 1.2 & 0.31 & & 3 \\
\hline Blattodea & 1 & 1.3 & 0.18 & & 1 & 0.4 & 0.01 & & 2 \\
\hline Isoptera & & & & & 59 & 23.6 & 3.53 & & 59 \\
\hline Dermaptera & 1 & 1.3 & 0.22 & & 3 & 1.2 & 0.18 & & 4 \\
\hline Psocoptera & 1 & 1.3 & 0.18 & & & & & & 1 \\
\hline Hemiptera Heteroptera & & & & & 5 & 2.0 & 0.68 & & 5 \\
\hline Hemiptera non-Heteroptera & 6 & 7.7 & 3.91 & $4.7(1)$ & 1 & 0.4 & 0.01 & & 7 \\
\hline Coleoptera & 19 & 24.4 & 39.72 & $1.6-5.3(13)$ & 30 & 12.0 & 16.17 & $2.4-11.6(14)$ & 49 \\
\hline Diptera & 1 & 1.3 & 1.96 & $5.1(1)$ & & & & & 1 \\
\hline Hymenoptera non-Formicidae & 12 & 15.4 & 23.58 & $1.2-6.2(11)$ & 11 & 4.4 & 2.00 & $3.0-7.3(4)$ & 23 \\
\hline Formicidae & 22 & 28.2 & 21.24 & $1.0-2.5(11)$ & 80 & 32.0 & 61.88 & $2.2-7.3(37)$ & 102 \\
\hline Insect egg & 3 & 3.8 & & $0.7-0.8(2)$ & & & & & 3 \\
\hline Insect larvae & 4 & 5.1 & 3.79 & $7.8-9.6(4)$ & 25 & 10.0 & 6.95 & $2.3-22.4(18)$ & 29 \\
\hline Araneae & 5 & 6.4 & 4.50 & $4.8-9.0(4)$ & 17 & 6.8 & 6.60 & $3.4-12.2(15)$ & 22 \\
\hline Pseudoscorpiones & 1 & 1.3 & 0.09 & & 4 & 1.6 & 0.58 & & 5 \\
\hline Opiliones & & & & & 4 & 1.6 & 0.53 & & 4 \\
\hline Diplopoda & 1 & 1.3 & 0.65 & & 4 & 1.6 & 0.58 & & 5 \\
\hline $\begin{array}{l}\text { Miconia budlejoides Triana } \\
\text { (Melastomataceae)* }\end{array}$ & & & & & 1 & 0.4 & & & 1 \\
\hline Melastomataceae* & & & & & 2 & 0.8 & & & 2 \\
\hline Unidentified vegetable matter & 1 & 1.3 & & & & & & & \\
\hline Total & 78 & & 100.00 & & 250 & & 100.00 & & 328 \\
\hline
\end{tabular}

Freq. $=$ frequency; $\mathrm{AI}=$ index of alimentary importance; $\mathrm{n}=$ number of prey with sizes obtained from linear regression equations. $*=$ seeds. 
items were insect larvae, found mainly in the feces of C. lineata, and Araneae (Table 1).

The observed niche overlap was 0.618 and this value does not differ from the expected ( $\mathrm{p}$ observed $\leq$ expected $=0.934$ ), so that the data does not suggest the existence of resource partitioning based only on taxonomic units consumed (Figure 1). However, even with approximately one third of arthropods identified in the $\operatorname{diet}$ of M. leucoblephara in relation to $C$. lineata, the number of identified arthropod groups was almost the same for the two species (12 for M. leucoblephara and 14 for C. lineata). As a consequence, $M$. leucoblephara showed a niche greater than that of C. lineata $(\mathrm{p}<0.001)$ (Figure 2). Insect larvae were the larger items consumed by both species but striking differences in prey size in the diet of both species were observed for Coleoptera and Formicidae (Table 1). In general, there were differences in prey size $(\mathrm{p}<0.001)$, and $C$. lineata, with a higher body mass $(\mathrm{p}<0.001)$, consumed larger preys (Figure 3).

\section{Discussion}

Both species consumed greater proportions of the arthropods that are naturally abundant taxa, such as Coleoptera, non-Formicidae Hymenoptera (bees and wasps), and Formicidae. Except for Hymenoptera non-Formicidae, other taxa were also very common in the litter (Pearson and Derr, 1985; Mestre et al., 2010). Thus it seems plausible that these birds feed opportunistically and the diet represents, in general, the resources found in the environment. In recent studies, Lima et al. (2011) and Lima and Manhães (2009) found that either C. lineata as Basileuterus culicivorus, formerly congeneric with $M$. leucoblephara, showed no preference for prey types, but there are no specific studies on the prey selection of M. leucoblephara.

There are some differences between the diet of the two species, especially in the exclusive consumption of Isoptera, Hemiptera Heteroptera, Orthoptera and Opiliones by $C$. lineata, and insect eggs and Diptera by M. leucoblephara. Although some of these differences may be due to chance, considering the low proportions of these taxa in the diets, the presence of taxa exclusive to the diet of $C$. lineata may indicate a greater ability of this species to tolerate the arthropods that carry chemical defenses (allomones) against predation as Isoptera and Hemiptera Heteroptera (Evans and Schmidt, 1990; Gullan and Cranston, 2007). Coleoptera also show a wide ability to use chemical defenses (Evans and Schmidt, 1990), but are the most numerous group of arthropod in terms of species (Triplehorn and Johnson, 2011) and it is not surprising that many taxa within the order are the common prey of birds.

The diet of both species also shows both similarities and differences compared to the findings of other authors. For example, there was considerable fluctuation in the diet composition of $M$. leucoblephara when compared to data from Chatellenaz (2008) in Argentina, who identified only 7 orders (Hemiptera, Coleoptera, Hymenoptera, Lepidoptera, Diptera, Araneae and Pseudoscorpiones), and Lopes et al. (2005) in Minas Gerais, who found only two orders (Coleoptera and Hymenoptera), with a greater prevalence of Formicidae. These differences are most likely related to sampling artifacts: the largest number of items identified and quantified in Ibitipoca against data from Argentina $(78 \times 54$ fragments plus others not

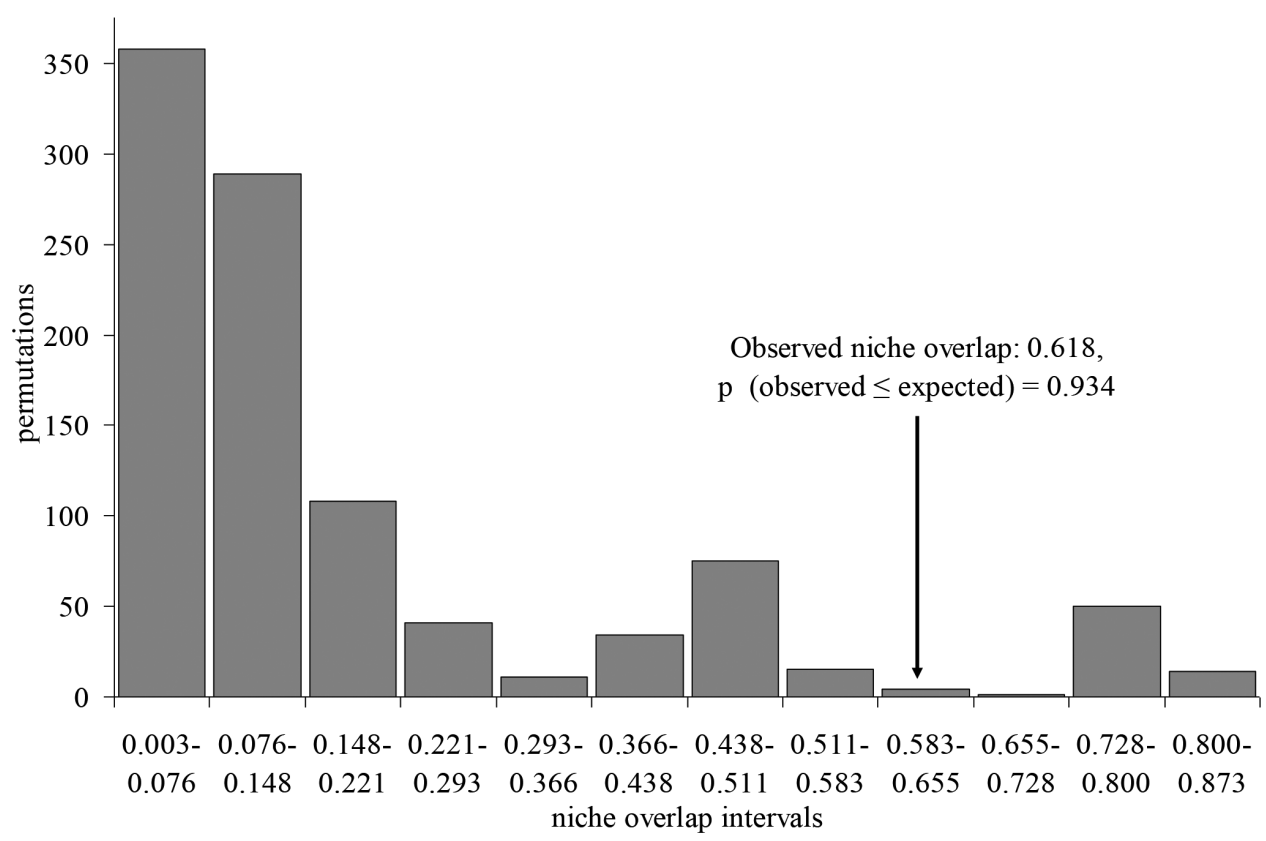

Figure 1. Pianka's niche overlap between Myiothlypis leucoblephara and Conopophaga lineata, based on types (taxons) of feeding items. The observed overlap did not differ from that obtained in 1000 permutations. 


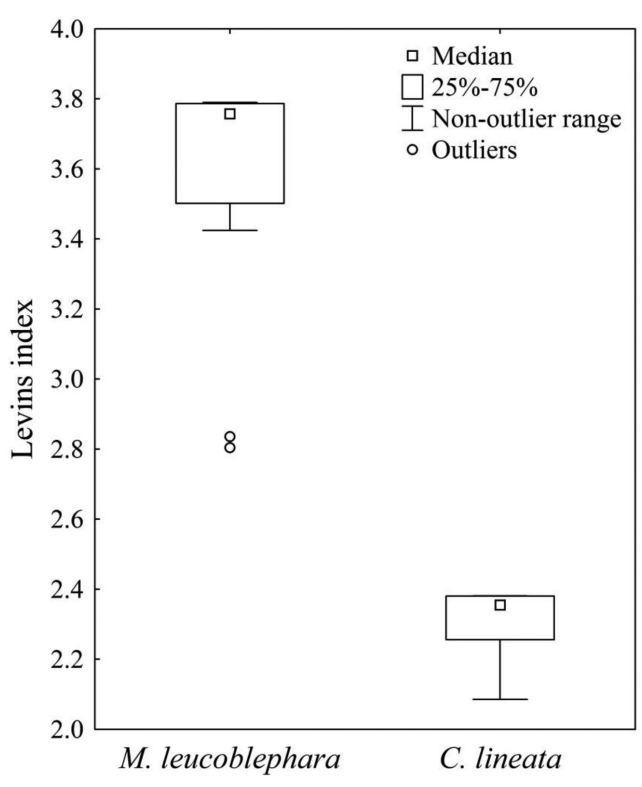

Figure 2. Levins' niche breadth obtained for Myiothlypis leucoblephara and Conopophaga lineata based on different types of prey, calculated by the Jackknife method ( $\mathrm{n}=16$ for both species).

quantified by Chatellenaz) and the largest number of samples (10 fecal samples $\times 2$ regurgitates) in relation to the data from Minas Gerais probably allowed a greater variety in types of prey items.

In general, the diet composition of $C$. lineata in Ibitipoca is similar to that described by Durães and Marini (2005), Lopes et al. (2005) and Lima et al. (2011), but the latter two authors did not find Isoptera in the diet. The alimentary importance of Isoptera for $C$. lineata in Ibitipoca was low, however, indicating many individual preys concentrated in few fecal samples. This suggests possible predation on nests or swarms of these social insects. On the other hand, the absence or low frequency of flying, agile or quick escape response arthropods, such as Diptera, Hymenoptera non-Formicidae, Orthoptera and Araneae, in the diet of both species is a pattern found by those authors and also in Ibitipoca. Reports of the feeding behavior of both species show that they capture prey when perched or in short and occasional flights (Willis et al., 1983; Mendonça-Lima et al., 2004), which seems to be more suited to catching prey such as Formicidae, many Coleoptera, insect larvae and Isoptera, despite the proportion and importance of Hymenoptera non-Formicidae consumed by M. leucoblephara.

The contrasts in the diet of the birds were not sufficient to reveal differences in niche overlap based on types of consumed items. As fecal samples and stomach contents provide highly fragmented materials, allowing only low taxonomic identification, in general at the order level, it is possible that greater differences are not detected by the limited accuracy of identifying the preys (Chapman and
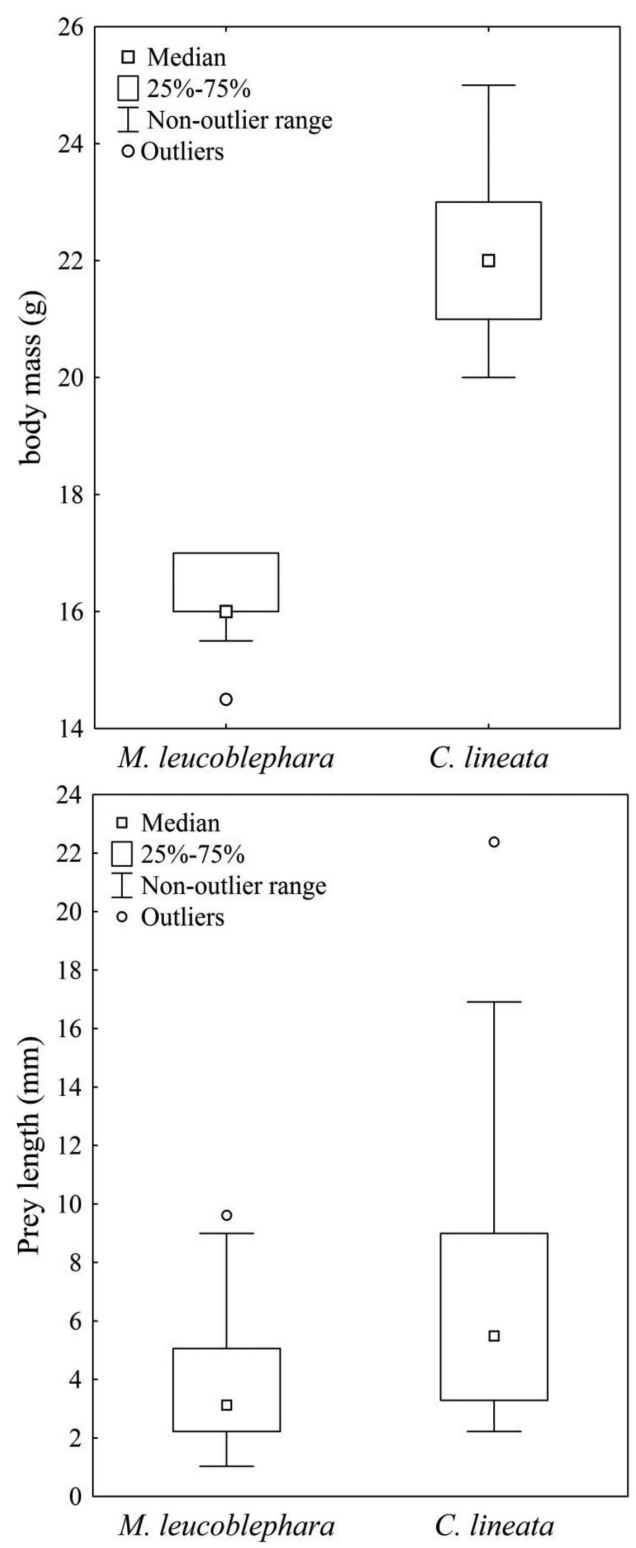

Figure 3. Comparison between the body mass of birds and lengths of prey consumed by Myiothlypis leucoblephara and $C$. lineata, indicating that the species with larger body mass $(C$. lineata $)$ also consumed larger arthropods.

Rosenberg, 1991; Mestre et al., 2010). However, this level of identification has allowed differences to be detected in other studies (Sherry, 1984; Poulin and Lefebvre, 1996; Yard et al., 2004). In contrast, ecological differences were seen in relation to niche width. Myiothlypis leucoblephara seems to have a more general diet than $C$. lineata because, even with fewer samples and identified items, they consumed almost the same number of taxa and the number of items was more uniform, whereas Formicidae was an item of very high alimentary importance in the $\operatorname{diet}$ of $C$. lineata. Despite not showing preference for any particular type 
of prey (Lima et al., 2011), as a follower of army ants, C. lineata can ingest them accidentally (Willis et al., 1983) or a possible ability to consume unpalatable prey may again be the key to explaining why ants are so much more common in the diet of $C$. lineata in relation to other species of insectivorous birds in the understorey, despite being an item of low nutritional value (Poulin and Lefebvre, 1996) but this difference remains unclear.

Another important difference found was differential consumption relative to the size of the prey. Conopophaga lineata regularly consumed larger prey than M. leucoblephara and also presented greater body size. Despite being only a single pair of species, these results are similar to those found by Hespenheide (1971) for various groups of birds, where species pairs were compared in relation to feeding habits. He noted that the birds shared resources based more on size than on the taxonomic composition of prey items. If we consider that prey abundance decreases with body size (Stork and Blackburn, 1993; Mestre et al., 2010), it is plausible to suggest that their availability also decreases. So smaller arthropods must be overabundant items, while the largest would be more limited resources and the birds seem to differ in the use of arthropods in function of the size. There is a positive relationship between the amplitude of a predator niche and body mass, because larger predators can consume prey of different sizes, while smaller predators consume smaller preys (Costa et al., 2008). So, while differences in the proportions of types of arthropods consumed by birds studied in Ibitipoca were not enough to reveal segregation in their feeding niches, the divergence in resource use was mainly due to the size of the prey.

\section{Acknowledgements}

We are grateful to the Instituto Estadual de Florestas (IEF) of the state of Minas Gerais for authorizing the research in the Ibitipoca State Park. We also thank Ricardo Oliveira Garcia for field support. The Centro Nacional de Pesquisa para a Conservação das Aves Silvestres (CEMAVE/IBAMA) supplied the bands and banding license.

\section{References}

ARAGONA, M. and SETZ, E.Z.F., 2001. Diet of maned wolf, Chrysocyon brachyurus (Mammalia: Canidae), during wet and dry seasons at Ibitipoca State Park, Brazil. Journal of Zoology, vol. 254, no. 1, pp. 131-136. http://dx.doi.org/10.1017/S0952836901000620.

BERGALLO, H.G. and ROCHA, F.D., 1994. Spatial and trophic niche differentiation in two sympatric lizards (Tropidurus torquatus and Cnemidophorus ocellifer) with different foraging tactics. Australian Journal of Ecology, vol. 19, no. 1, pp. 72-75. http:// dx.doi.org/10.1111/j.1442-9993.1994.tb01545.x.

BLAKE, J.G. and HOPPES, W.G., 1986. Influence of resource abundance on use of tree-fall gaps by birds in an isolated woodlot. The Auk, vol. 103, no. 2, pp. 328-340.

BURGER, J.C., PATTEN, M.A., ROTENBERRY, J.T. and REDAK, R.A., 1999. Foraging ecology of the California gnatcatcher deduced from fecal samples. Oecologia, vol. 120, no. 2, pp. 304-310. http:// dx.doi.org/10.1007/s004420050862.

CARVALHO, L.M.T., FONTES, M.A.L. and OLIVEIRA-FILHO, A.T., 2000. Tree species distribution in canopy gaps and mature forest in an area of cloud forest of the Ibitipoca Range, southeastern Brazil. Plant Ecology, vol. 149, no. 1, pp. 9-22. http:// dx.doi.org/10.1023/A:1009836810707.

CASTRO-ARELLANO, I. and LACHER JUNIOR, T.E., 2009. Temporal niche segregation in two rodent assemblages of subtropical Mexico. Journal of Tropical Ecology, vol. 25, no. 6, pp. 593-603. http://dx.doi.org/10.1017/S0266467409990186.

CHAPMAN, A. and ROSENBERG, K.V., 1991. Diets of four sympatric Amazonian woodcreepers (Dendrocolaptidae). The Condor, vol. 93, no. 4, pp. 904-915. http://dx.doi.org/10.2307/3247725.

CHATELLENAZ, M.L., 2008. Ecología alimentaria de dos especies simpátricas del género Basileuterus en el noreste de Argentina. Hornero, vol. 23, no. 2, pp. 87-93.

COSTA, G.C., VITT, L.J., PIANKA, E.R., MESQUITA, D.O. and COLLI, G.R., 2008. Optimal foraging constrains macroecological patterns: body size and dietary niche breadth in lizards. Global Ecology and Biogeography, vol. 17, no. 5, pp. 670-677. http:// dx.doi.org/10.1111/j.1466-8238.2008.00405.x.

D'ANGELO NETO, S., VENTURIN, N., OLIVEIRA-FILHO, A.T. and COSTA, F.A.F., 1998. Avifauna de quatro fisionomias florestais de pequeno tamanho (5-8 ha) no campus da UFLA. Brazilian Journal of Biology $=$ Revista Brasileira de Biologia, vol. 58 , no. 3 , pp. $463-472$.

DURÃES, R. and MARINI, M.A., 2005. A quantitative assessment of bird diets in the Brazilian Atlantic forest, with recommendations for future diet studies. Ornitologia Neotropical, vol. 16, no. 1, pp. $65-83$.

EVANS, D.L. and SCHMIDT, J.O., 1990. Insect defenses: adaptive mechanisms and strategies of prey and predators. Albany: State University of New York Press. 482 p.

GOMES, V.S., ALVES, V.S. and RIBEIRO, J.R.I., 2001. Itens alimentares encontrados em amostras de regurgitação de Pyriglena leucoptera (Vieillot) (Aves, Thamnophilidae) em uma floresta secundária no Estado do Rio de Janeiro. Revista Brasileira de Zoologia, vol. 18, no. 4, pp. 1073-1079. http://dx.doi.org/10.1590/ S0101-81752001000400005.

GOTELLI, N.J. and ENTSMINGER, G.L., 2004 [viewed 8 August 2004]. EcoSim: null models software for ecology. Version 7 [online]. Jericho: Acquired Intelligence Inc. \& Kesey-Bear. Available from: http://garyentsminger.com/ecosim/

GULLAN, P.J. and CRANSTON, P.S., 2007. Os insetos: um resumo de entomologia. São Paulo: Roca. 440 p.

HAMMER, Ø., HARPER, D.A.T. and RYAN, P.D., 2001. PAST: Paleontological Statistics Software Package for education and data analysis. Palaeontologia Electronica, vol. 4, no. 1, pp. 1-9.

HASUI, E., GOMES, V.S.M., KIEFER, M.C., TAMASHIRO, J. and SILVA, W.R., 2009. Spatial and seasonal variation in niche partitioning between blue manakin (Chiroxiphia caudata) and greenish schiffornis (Schiffornis virescens) in southeastern Brazil. Studies on Neotropical Fauna and Environment, vol. 44, no. 3, pp. 149-159. http://dx.doi.org/10.1080/01650520903381729.

HESPENHEIDE, H.A., 1971. Food preference and the extent of overlap in some insectivorous birds, with special reference to the Tyrannidae. The Ibis, vol. 113, no. 1, pp. 59-72. http://dx.doi. org/10.1111/j.1474-919X.1971.tb05123.x. 
JAKSIC, F., 2000. Ecología de comunidades. Santiago: Ediciones Universidad Catolica de Chile. 233 p.

KRAUCZUK, E.R., 2008. Riqueza específica, abundancia y ambientes de las aves de Corpus Christi, San Ignacio, Misiones, Argentina. Lundiana, vol. 9, no. 1, pp. 29-39.

LEVINS, R., 1968. Evolution in changing environments. Princeton: Princeton University Press. 132 p. Monographs in Population Biology, no. 2.

LIMA, A.L.C. and MANHÃES, M.A., 2009. Hábitos alimentares de Basileuterus culicivorus (Aves: Parulidae) em uma área de Mata Atlântica secundária, sudeste do Brasil. Biota Neotropica, vol. 9, no. 3, pp. 137-143. http://dx.doi.org/10.1590/S167606032009000300013 .

LIMA, A.L.C., MANHÃES, M.A. and PIRATELLI, A.J., 2011. Ecologia trófica de Conopophaga lineata (Conopophagidae) em uma área de mata secundária no sudeste do Brasil. Revista Brasileira de Ornitologia, vol. 19, no. 3, pp. 315-322.

LOPES, L.E., FERNANDES, A.M. and MARINI, M.A., 2005. Diet of some Atlantic Forest birds. Ararajuba, vol. 13, no. 1, pp. $95-103$.

MANHÃES, M.A. and DIAS, M.M., 2008. Diet and feeding preference of the Plain Antvireo (Dysithamnus mentalis) in an area of Brazilian Atlantic forest. Ornitologia Neotropical, vol. 19 , no. 3 , pp. $417-426$.

MANHÃES, M.A., 2003. Variação sazonal da dieta e do comportamento alimentar de traupíneos (Passeriformes: Emberizidae) em Ibitipoca, Minas Gerais, Brasil. Ararajuba, vol. 11 , no. 1 , pp. 45-55.

MANHÃES, M.A., LOURES-RIBEIRO, A. and DIAS, M.M., 2010. Diet of undestorey birds in two Atlantic Forest areas of southeast Brazil. Journal of Natural History, vol. 44, no. 7-8, pp. 469-489. http://dx.doi.org/10.1080/00222930903380947.

MARINI, M.A., 2010. Bird movement in a fragmented Atlantic Forest landscape. Studies on Neotropical Fauna and Environment, vol. 45, no. 1, pp. 1-10. http://dx.doi.org/10.1080/01650521003656606.

MARTINEZ, C., 2004. Food and niche overlap of the scarlet ibis and the yellow-crowned night heron in a tropical mangrove swamp. Waterbirds, vol. 27, no. 1, pp. 1-8. http://dx.doi.org/10.1675/15244695(2004)027[0001:FANOOT]2.0.CO;2.

MCGAVIN, G.C., 2000. Insects, spiders and other terrestrial arthropods. London: Dorling Kindersley Book. 256 p.

MENDONÇA-LIMA, A., HARTZ, S.M. and KINDEL, A., 2004. Foraging behavior of the White-browed (Basileuterus leucoblepharus) and the Golden-crowned (Basileuterus culicivorus) Warblers in a semidecidual forest in southern Brazil. Ornitologia Neotropical, vol. 15, no. 1, pp. 5-15.

MESTRE, L.A.M., COHN-HAFT, M. and DIAS, M.M., 2010. Diet and prey availability of terrestrial insectivorous birds prone to extinction in Amazonian forest fragments. Brazilian Archives of Biology and Technology, vol. 53, no. 6, pp. 1371-1381. http:// dx.doi.org/10.1590/S1516-89132010000600014.

MOREBY, S.J., 1988. An aid to identification of arthropod fragments in the faeces of gamebird chicks (Galliformes). The Ibis, vol. 130, no. 6, pp. 519-526. http://dx.doi.org/10.1111/j.1474919X.1988.tb02717.x.

NAOKI, K., 2007. Arthropod resource partitioning among omnivorous tanagers (Tangara spp.) in western Ecuador. The
Auk, vol. 124, no. 1, pp. 197-209. http://dx.doi.org/10.1642/00048038(2007)124[197:ARPAOT]2.0.CO;2.

NARANJO, L.G. and ULLOA, P.C., 1997. Diversidad de insectos $\mathrm{y}$ aves insectivoras de sotobosque en habitats perturbados de selva lluviosa tropical. Caldasia, vol. 19, no. 3, pp. 507-520.

PACHECO, J.F., PARRINI, R., LOPES, L.E. and VASCONCELOS, M.F., 2008. A avifauna do Parque Estadual do Ibitipoca e áreas adjacentes, Minas Gerais, Brasil, com uma revisão crítica dos registros prévios e comentários sobre biogeografia e conservação. Cotinga, vol. 30, pp. 16-32.

PEARSON, D.L. and DERR, J.A., 1985. Seasonal patterns of lowland forest floor arthropod abundance in southeastern Peru. Biotropica, vol. 18, no. 3, pp. 244-256. http://dx.doi.org/10.2307/2388493.

PIANKA, E.R., 1973. The structure of lizard communities. Annual Review of Ecology and Systematics, vol. 4, no. 1, pp. 53-74. http:// dx.doi.org/10.1146/annurev.es.04.110173.000413.

POULIN, B. and LEFEBVRE, G., 1996. Dietary relationships of migrant and resident birds from a humid forest in central Panama. The Auk, vol. 113, no. 2, pp. 277-287. http://dx.doi. org/10.2307/4088894.

RALPH, C.P., NAGATA, S.E. and RALPH, C.J., 1985. Analysis of droppings to describe diets of small birds. Journal of Field Ornithology, vol. 56, no. 2, pp. 165-174.

ROBINSON, S.K. and HOLMES, R.T., 1982. Foraging behavior of forest birds: the relationships among search tactics, diet, and habitat structure. Ecology, vol. 63, no. 6, pp. 1918-1931. http:// dx.doi.org/10.2307/1940130.

RODRIGUES, M., 1995. Spatial distribution and food utilization among tanagers in southeastern Brazil (Passeriformes: Emberizidae). Ararajuba, vol. 3, pp. 27-32.

SCHOENER, T.W., 1974. Resource partitioning in ecological communities. Science, vol. 185, no. 4145, pp. 27-39. http://dx.doi. org/10.1126/science.185.4145.27. PMid:17779277.

SHERRY, T.W., 1984. Comparative dietary ecology of sympatric, insectivorous Neotropical Flycatchers (Tyrannidae). Ecological Monographs, vol. 54, no. 3, pp. 313-338. http://dx.doi. org/10.2307/1942500.

STORK, N.E. and BLACKBURN, T.M., 1993. Body size and biomass of arthropods in tropical forest. Oikos, vol. 67, no. 3, pp. 483-489. http://dx.doi.org/10.2307/3545360.

STOUFFER, P.C. and BIERREGAARD JUNIOR, R.O., 1995. Use of Amazonian forest fragments by understory insectivorous birds. Ecology, vol. 76, no. 8, pp. 2429-2445. http://dx.doi. org/10.2307/2265818.

TRIPLEHORN, C.A. and JOHNSON, N.F., 2011. Estudo dos insetos. São Paulo: Cengage Learning. 809 p.

VIEIRA, E.M. and PORT, D., 2006. Niche overlap and resource partitioning between two sympatric fox species in southern Brazil. Journal of Zoology, vol. 272, no. 1, pp. 57-63. http://dx.doi. org/10.1111/j.1469-7998.2006.00237.x.

WHITAKER JUNIOR, J.O., 1998. Food habits analysis of insectivorous bats. In: T.H. KUNZ, ed. Ecological and behavioral methods for the study of bats. Washington: Smithsonian Press, pp. 171-189.

WILLIS, E.O., 1979. The composition of avian communities in remanescent woodlots in southern Brazil. Papéis Avulsos de Zoologia, vol. 33, no. 1, pp. 1-25. 
WILLIS, E.O., ONIKI, Y. and SILVA, W.R., 1983. On the behaviour of Rufous Gnateaters (Conopophaga lineata, Formicariidae). Naturalia, vol. 8, pp. 67-93.

YABE, R.S., MARQUES, E.J. and MARINI, M.A., 2010. Movements of birds among natural vegetation patches in the Pantanal, Brazil. Bird Conservation International, vol. 20, no. 4, pp. 400-409. http://dx.doi.org/10.1017/ S0959270910000067.

YARD, H.K., VAN RIPER, C., BROWN, B.T. and KEARSLEY, M.J., 2004. Diets of insectivorous birds along the Colorado River in Grand Canyon, Arizona. The Condor, vol. 106, no. 1, pp. 106115. http://dx.doi.org/10.1650/7242. 